\title{
A possible source of error in the diagnosis of phaeochromocytoma
}

\author{
D. W. NEILL, I. J. CARRÉ, R. L. MCCORRY, AND R. H. THOMPSON \\ From the Royal Belfast Hospital for Sick Children and the Biochemical Laboratory, \\ Royal Victoria Hospital, Belfast, Northern Ireland
}

SYNOPSIS The finding is reported of an apparent high level of urinary catechol amines in a child with pyelonephritis. As a result of investigations the source of error was traced to tetracycline therapy.

The biochemical estimation of catechol amines in the urine is now an established method of diagnosing phaeochromocytoma (Engel and von Euler, 1950; Goldenberg, Serlin, Edwards, and Rapport, 1954). Though more accurate than tests involving the use of adrenolytic drugs such as dibenyline, piperoxane (benzodioxane), and phentolamine (rogitine) false positive results have occasionally been reported. The recent description (Malbin, 1959) of a patient, whose urine contained 10 times the normal concentration of catechol amines but in whom no adrenal tumour could be found, prompts the description of the following case history and observations.

\section{CASE REPORT}

E.P., a girl aged 3 years 7 months, attended the Royal Belfast Hospital for Sick Children in April 1957, because of recurrent attacks of otitis media. There was no history of any other illness. Her blood pressure was $95 / 60 \mathrm{~mm}$. Hg. Albuminuria was detected on routine testing. The urinary deposit showed a few pus cells only; culture was sterile on three occasions. The blood urea was $21 \mathrm{mg}$. per $100 \mathrm{ml}$.

Towards the end of May she developed polydypsia, cardiac enlargement (confirmed radiographically), and hypertension (blood pressure $180 / 130 \mathrm{~mm}$. Hg). The fundi were normal in appearance. Femoral pulsation was felt.

The urine contained protein, 0.1 to $0.2 \mathrm{~g} . \%$, and pus cells 5 to 15 per high power field (centrifuged deposit). Two specimens were sterile; one specimen on culture yielded growth of $B$. coli sensitive to oxytetracycline.

Blood urea was $24 \mathrm{mg}$. per $100 \mathrm{ml}$.

Intravenous pyelography showed the soft tissue outline of the right kidney to be smaller than the left. Dye was well secreted on both sides. Neither the pelvis nor the calyces were distorted.

Received for publication 6 June 1960.
The patient was thought to have chronic pyelonephritis and on 6 June 1957 was started on a course of oxytetracycline $125 \mathrm{mg}$. six-hourly. The catechol amine content of urine collected on 20 June was reported as 470 micrograms per 24 hours (Hingerty's method, 1957; normal value $=40 \mu \mathrm{g}$. $/ 24$ hours). This high level suggested a phaeochromocytoma as the cause of the hypertension. However, an intravenous phentolamine (rogitine) test produced no fall in blood pressure. This observation cast doubt on the validity of the urine catechol amine result and this was accordingly re-estimated. On this second occasion a value of 67 micrograms per 24 hours was obtained. (Antibiotic therapy had been discontinued one week previously.)

In early July the patient's condition deteriorated rapidly and cardiac failure developed. Improvement followed treatment with digoxin, mecamylamine, and a low-salt diet though hypertension persisted (blood pressure $170 / 120$ to $200 / 140 \mathrm{~mm}$. $\mathrm{Hg}$ ).

On 31 July 1957 a right-sided nephrectomy was performed. The kidney, which was grossly scarred and contracted, showed on histological examination active and extensive chronic pyelonephritis and marked endarteritic vascular changes.

\section{BIOCHEMICAL INVESTIGATIONS}

A specimen of urine (about $200 \mathrm{ml}$.) from the child was analysed by the Hingerty (1957) modification of the method described by von Euler and Floding (1955). This technique involves the extraction of the amines on alumina and treatment of the eluate from the latter with alkaline potassium ferricyanide in the presence of ascorbic acid. The trihydroxyindole derivatives so formed (Lund, 1952) exhibit strong green fluorescence under ultra-violet light and the intensity of this is compared with that produced by urine to which known additions of noradrenaline have been made.

Using this test the child's urine showed a fluorescence well in excess of that obtained from urine to which had been added 10 micrograms of noradrenaline per $100 \mathrm{ml}$. 
urine. The presumptive diagnosis of phaeochromocytoma suggested by this result was thought by the clinicians to be unlikely and a sample of the alumina extract from the urine was examined by the Department of Physiology of Queen's University, Belfast, using a rat uterus assay preparation. The apparent catechol amine activity was less than 0.001 micrograms per ml. of the original urine, i.e., less than 1/100 of the value obtained by the Hingerty method, and this was confirmed by tests on a further urine specimen from the patient using the rabbit blood pressure assay.

It is recognized that using the Hingerty method a positive result can occasionally be given by substances in the urine other than catechol amines (Frazer, 1957). Tetracycline (achromycin) has been incrimated in this respect (Glenn, 1959) and the fact that oxytetracycline (terramycin) was being given to our patient at the time of the initial catechol amine estimation suggested that this antibiotic might be the substance responsible for the observed false positive result. The fact that the catechol amine value had fallen to near normal levels when repeated one week after discontinuing antibiotic therapy gave extra support to this belief. Accordingly, the following experiment was set up in vitro. Noradrenaline, reserpine (serpasil), digoxin, mecamylamine (inversine), and oxytetracycline (terramycin) were added to separate urine specimens obtained from healthy individuals. These were then carried through the following biochemical extraction.

Each urine sample was evaporated under vacuum after bringing to $p \mathrm{H} 4$ and the dried extracts treated with acid acetone. The insoluble matter was discarded and after evaporation to dryness the residue was again taken up in acid acetone. The evaporation was repeated and the final residue was dissolved in acetone and applied to paper strips for chromatography. This was carried out in the dark using the butanol-acetic-acid-water system. The dried strips were sprayed with potassium ferricyanide and alkaline ascorbic acid and examined under ultra-violet light for the appearance of fluorescence.

The urine samples containing noradrenaline and oxytetracycline each gave a bright fluorescence (Table I).

\section{TABLE I}

$\begin{array}{ll}\text { Substance Added } & \begin{array}{l}\text { Colour of Fluorescence under Ultraviolet } \\ \text { to Urine }\end{array} \\ \text { Stimulus after Ferricyanide Oxidation }\end{array}$

\begin{tabular}{ll}
\hline Noradrenaline & Bright green \\
Reserpine & White \\
Digoxin & Non-specific \\
Mecamylamine & Non-specific \\
Oxytetracycline & Bright yellow-green
\end{tabular}

Since the estimation of catechol amines is based on the intensity of their fluorescence it is clear from these observations that false positive results could be obtained in patients on oxytetracycline should this antibiotic be excreted in the urine in sufficient concentration. To test this possibility catechol amine estimations were carried out by the Hingerty (1957) method on urine collected from 11 children who were confined to bed and receiving treatment with antibiotics of the tetracycline group. Specimens were collected one and seven days after starting treatment.
The results, which are set out in Table II, show ine many instances a significant rise in the urine catechol

\begin{tabular}{|c|c|c|c|c|}
\hline \multirow[t]{2}{*}{$\begin{array}{l}\text { Patient } \\
\text { Number }\end{array}$} & \multirow[t]{2}{*}{ Antibiotic } & \multirow[t]{2}{*}{$\begin{array}{l}\text { Daily Dose } \\
\text { (mg./kg. } \\
\text { body weight) }\end{array}$} & \multicolumn{2}{|c|}{$\begin{array}{l}{ }^{1} \text { Catechol Amines } \\
\text { Noradrenaline in } \\
\text { Hours ( } \mathrm{gg} .)\end{array}$} \\
\hline & & & $\begin{array}{l}\text { After } \\
\text { One } \\
\text { Day }\end{array}$ & $\begin{array}{l}\text { After } \\
\text { Seven } \\
\text { Days }\end{array}$ \\
\hline 1 & Tetracycline & 20 & 98 & 65 \\
\hline 2 & Tetracycline & 14 & 54 & 106 \\
\hline 3 & Tetracycline & 21 & 93: & 124 \\
\hline 4 & Chlortetracycline & $21 \cdot 5$ & 83 & 102 \\
\hline 5 & Chlortetracycline & 16 & 73 & 135 \\
\hline 6 & Chlortetracycline & 11 & 106 & 104 \\
\hline 7 & Erythromycin & 24 & 65 & 135 \\
\hline 8 & Erythromycin & 27 & 53 & 79 \\
\hline 9 & Erythromycin & 24 & 39 & 69 \\
\hline 10 & Oxytetracycline & $22 \cdot 5$ & 86 & 57 \\
\hline 11 & Oxytetracycline & 29 & 26 & 76 \\
\hline
\end{tabular}

'Estimated by the method of Hingerty (1957)

amine levels (normal values for children $=40 \mu \mathrm{g} . / 24$ hours). There was no obvious relationship between the catechol amine values and either the dose, method of. administration, or type of antibiotic tested. On the other $\square$ hand, the values recorded after a seven-day period of treatment tended to be higher than those noted after only 24 hours of therapy.

\section{DISCUSSION}

The investigations described show that when esti- $\frac{}{3}$ mated by the Hingerty method a high urine catechol amine value can be obtained if the patient is receiving? treatment with one of the tetracycline group of anti-궁 biotics. Although raised, the levels noted in the group of children receiving treatment with antibiotics of the tetracycline group were not as high as the initial value recorded in the patient E.P. Two factors probably responsible for this discrepancy음 would seem to be the more prolonged period of treatment (two weeks) and the much higher dosage음 schedule used in the case of E.P. (47 mg./kg.). Nevertheless, the urine catechol amine values . recorded were some two to three times in excess of $\mathrm{N}$ the normal standards for children accepted in our laboratory using this method. Since results of this $\sigma$ order have been noted in patients with phaeochromocytoma (McMillan, 1957), it is clearly essential $\frac{\mathrm{C}}{\bar{D}}$ that patients should be taken off all tetracycline antibiotics some days before collecting urine for the biochemical estimation of catechol amines.

We should like to thank Professor F. M. B. Allen, of the $\frac{\overparen{D}}{\mathbb{D}}$ Department of Child Health, The Queen's University, 음 Belfast, for his interest and encouragement, and Pro fessor A. D. M. Greenfield, of the Department of $\varnothing$ Physiology, for the biological assays. 
REFERENCES

Engel, A., and von Euler, U. S. (1950). Lancet, 2, 387. Frazer, S. C. (1957). Ibid, 1, 932.

Glenn, J. H. (1959). J. med. Lab. Technol., 16, 161.

Goldenberg, M., Serlin, I., Edwards, T., and Rapport, M. M. (1954). Amer. J. Med., 16, 310.
Hingerty, D. (1957). Lancet, 1, 766.

Lund, A. (1952). Scand. J. clin. Lab. Invest., 4, 263.

Malbin, B. (1959). Ann. intern. Med., 51, 613.

McMillan, Mary (1957). Lancet, 1, 715.

von, Euler, U. S., and Floding, I. (1955). Acta physiol. scand., 33, Suppl. 118, p. 56.

\section{The May 1961 Issue}

\section{THE MAY 1961 ISSUE CONTAINS THE FOLLOWING PAPERS}

A clinicopathological study of benign Hodgkin's disease P. J. DAWSON and C. V. HARRISON

Tumours of salivary tissue J. MALCOLM CAMERON

An assessment of the anatomical factor in cor pulmonale in emphysema M. S. DUNNILL

Nocardiosis in anaemic patients given steroids D. N. WHITMORE, G. A. GRESHAM, and M. J. GRAYSON

A family study of the biochemical defects in Wilson's disease J. F. SOOTHILL, J. D. BLAINEY, F. C. NEALE, M. FISCHER-WILLIAMS, and S. C. MELNICK

A study of six representative methods of plasma bilirubin analysis DEREK WATSON and JANICE A. ROGERS

Hypercholesterolaemia and diabetes mellitus J. N. HARRIS-JONES and D. J. WARD

Multiple plasma enzyme activities in liver disease T. HARGREAVES, I. JANOTA, and M. J. H. SMITH

Soluble cerebral proteins in normal and oedematous brain J. N. CUMINGS
The usefulness of counting 'heat-affected' red cells as a guide to the risk of the later disappearance of red cells after burns ELIZABETH TOPLEY

The distribution of blood cells on haemacytometer counting chambers with special reference to the amended British Standards Specification 748 (1958) C. SANDERS and D. W. SKERRY

The defect of blood coagulation in joints A. J. HARROLD

A latex fixation test using British latex and bovine gamma globulin R. B. PAYNE

The testing of sterilizers: 2 Thermophilic spore papers J. C. KELSEY

\section{Technical methods}

An apparatus for measuring the tensile strength of blood clots R. G. MACFARLANE and A. H. TOMLINSON

An automatic staining machine for blood and marrow films on slides J. G. SELWYN

The Association of Clinical Pathologists: 66th general meeting

Book reviews

Copies are still available and may be obtained from the PUBLISHING MANAGER, BRITISH MEDICAL ASSOCIATION, TAVISTOCK SQUARE, W.C.1, price 17s. 6D. 